\title{
IMPACT ON CORPORATE MANAGEMENT BY INSTITUTIONAL INVESTORS
}

\author{
Michael Diederich
}

\section{Key words:}

Institutional shareholder, corporate governance, capital markets, shareholder value, voting power .

\begin{abstract}
:
Will give an overview of the increasing influence of institutional shareholder in public listed companies. This topic is getting more and more important because the dominance of the capital markets is increasing and institutional investors are asking for more voting power. One could see in the resent history that these shareholder use the voting power which in return has an impact on the corporate governance framework for companies. The aim of this paper is to evaluate the increasing dominance of institutional shareholder and to give an overview of the most used measures by institutional shareholders.
\end{abstract}

\section{Introduction}

Corporate governance and corporate management are becoming more and more important in today's capital markets. Particularly, the fast growing importance of institutional investors is a key factor which helps to explain the changing attitude of managers towards shareholders and corporate governance. Within academic literature, the issue of shareholder activism by institutional investors little analyzed so far. Furthermore, there are only a few surveys on the outcome of the influence by institutional investors on corporate management. Therefore, this paper aims to answer the following questions:

1. How was the development of shareholder activism?

2. Which options do institutional investors have to influence corporate management?

3. What is the empirical outcome of activism by institutional investors?

\section{Theoretical Differentiation of the Object of Investigation}

This chapter will provide a basis of fundamentals which are necessary for the elaboration of the problems, which are dealt with in this paper. In a first step, the basics of shareholder activism will be outlined. For the further development, it is essential to distinguish different kinds of investors.

\subsection{Shareholder Activism}

Historically, Shareholder Activism is not a new phenomenon. The first documented shareholding dates back to the year 1288. Since then, shareholders have access to the most basic 
"instrument" of activism, namely, to vote relative to their shareholdings on corporate issues like, personnel or initiatives. ${ }^{1}$

At first glance, the expression "Investorenaktivismus" is barely widespread in German literature. Consequently, it follows that there is no standard definition of this term. Even in English literature, where investor activism is a synonym for shareholder activism, it is hard to find a common prevalent definition. For the further procedure, shareholder activism is conceived as: proactive exercise of influence by shareholders on corporate management to achieve individual objectives. Furthermore, the term shareholder and stockholder will be used as synonym for the term investor. Shareholders of a listed company acquire a share in the company's equity by buying shares on the stock market. Stockholders are not entitled to interests nor do they have a right to redemption. But shareholders are not the only stakeholders who try to achieve their own goals. Typically, shareholders have the interest to, at least, receipt their money but more to increase their property and the value of their assets.

\subsection{Institutional Investors}

Whether investors actively influence corporate management depends on the type of investor one is referring to. Generally speaking, investors are characterized as individuals or firms who undertake investments. ${ }^{2}$ According to the Organization for Economic Cooperation and Development (further, OECD) "institutional investors are major collectors of savings and suppliers of funds to financial markets." 3 Following Schiereck, institutional investors are characterized by three main aspects: First, institutional investors act as an independent legal body. Second, their main business operations are alluding to the management and disposal of external finance through specially trained employees. Third, institutional investors are characterized by their portfolio holdings which are labeled by an above average volume of orders, which is able to influence financial markets. ${ }^{4}$ A detailed classification of institutional investors by the OECD is illustrated below.

\footnotetext{
See Ben-Ur (2007), p. 2.

See Gabler Wirtschaftslexikon (2004), p. 1597.

See OECD (2003), p. 9.

See Schiereck (1995), pp. 7 et seq.
} 


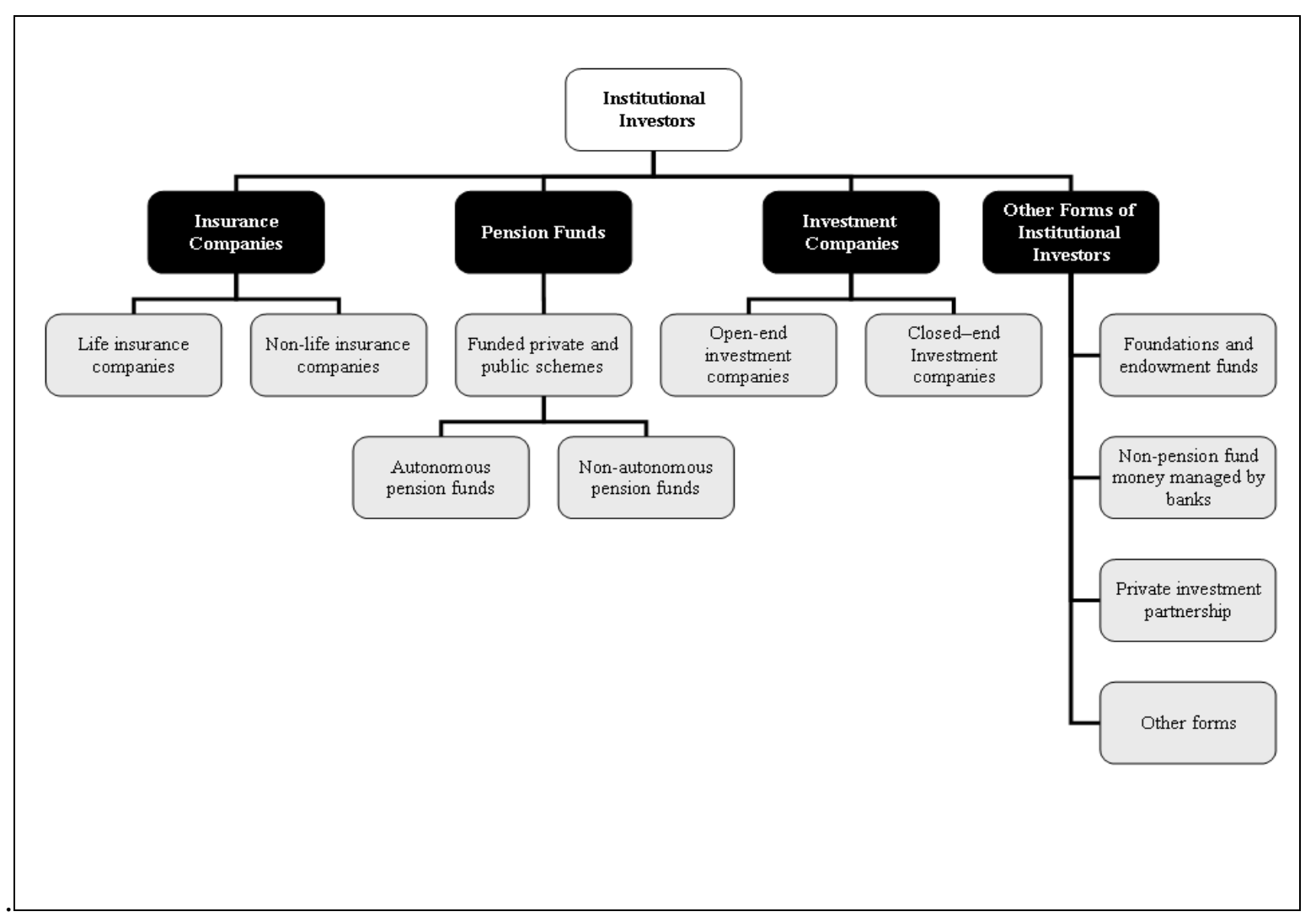

Figure 1: Classification of institutional investors by the OECD5

Deutsche Bundesbank defines institutional investors as investors who have enormous assets at their disposal and thereby using professional techniques to manage them. ${ }^{6}$ In a more narrow definition, Deutsche Bundesbank subsumes under the term "institutional investors": insurance companies, investment funds and pension funds. In addition, this definition is expanded by commercial banks and industry enterprises with substantial shareholdings

\subsection{Corporate Governance}

Shleifer and Vishny define corporate governance as: "[...] the ways in which suppliers of finance to corporations assure themselves of getting a return on their investment." From an academic point of view, this definition seems not to be sufficient and needs a more differentiated review. Against a larger economic background, corporate governance is only a small fraction of the context in which companies operate.

For example, other factors like economic policies as well as the degree of competition in factor and product markets do influence the behavior of a company. Moreover, corporate governance frameworks around the world are shaped by different legal, regulatory and institutional conditions. ${ }^{8}$ Thus, it is important that one can distinguish corporate governance between an internal and an external perspective. Last but not least, a functioning corporate governance framework does also help to increase the confidence in financial markets. A very interesting

\footnotetext{
See OECD (2004), p. 5.

See Deutsche Bundesbank (1998), p. 56.

7 See Shleifer and Vishny (1996), p. 2.

8 See OECD (2004), p. 12.
} 
view comes from Prof. Porvaznik and Coll. "[...] corporate governance to mean the protection of its liberty and flexibilty and the securing of its continuing ability to create riches and wealth that society depends on." $\mathrm{By}$ this definition one can see the relevance and importance not only for a company but for the whole society.

\subsection{Corporate Management}

The terms "Corporate Governance" and "Corporate Management" have to be distinguished. As outlined above, corporate governance deals with the regulatory framework to manage a company and to monitor the management. In contrast, corporate management deals with the targeted impact on internal processes by the management. ${ }^{10}$ Corporate management can be differentiated on the basis of several dimensions. Thus, one can distinguish the following dimensions:

- Extent (partial or total),

- Procedure (synoptically or incrementally) and

- Paradigm (systematic or constructivist).

Based on the comprehensiveness of corporate management models, all sub-functions of the term corporate management will be dealt with. In particular, this paper will emphasize on the sub-functions of corporate management, e.g. strategic planning and control aspects, information and communication, motivation and compensation as well as organizational and cultural aspects.

\section{Shareholder Activism by Institutional Investors in Germany - Status Quo}

The objective of this chapter is to outline the historical development of shareholder activism in Germany. Hence, it is necessary to present evidence on a growing institutional ownership in Germany as well as to assign reasons for such a development.

Figure 2 illustrates the development of German institutional investors from 2002 to 2007. Following the methodology from the OECD Statistical Yearbook, figure 2 shows the investments and holdings as a percentage of German GDP. ${ }^{11}$

See Prof. Jan Porvaznik and Coll. (2008), p. 373.

10 See Steinmann and Schreyogg (2005), pp. 3 et seq.

11 Unfortunately, data from the OECD ended at the end of 2001. As it seems not appropriate to use 7 year old data, I used data from Deutsche Bundesbank (2008), p. 52, Gesamtverbandverband deutscher Versicherungen (GDV) (2007), p. 24, Statistisches Bundesamt (2007), p. 623. 


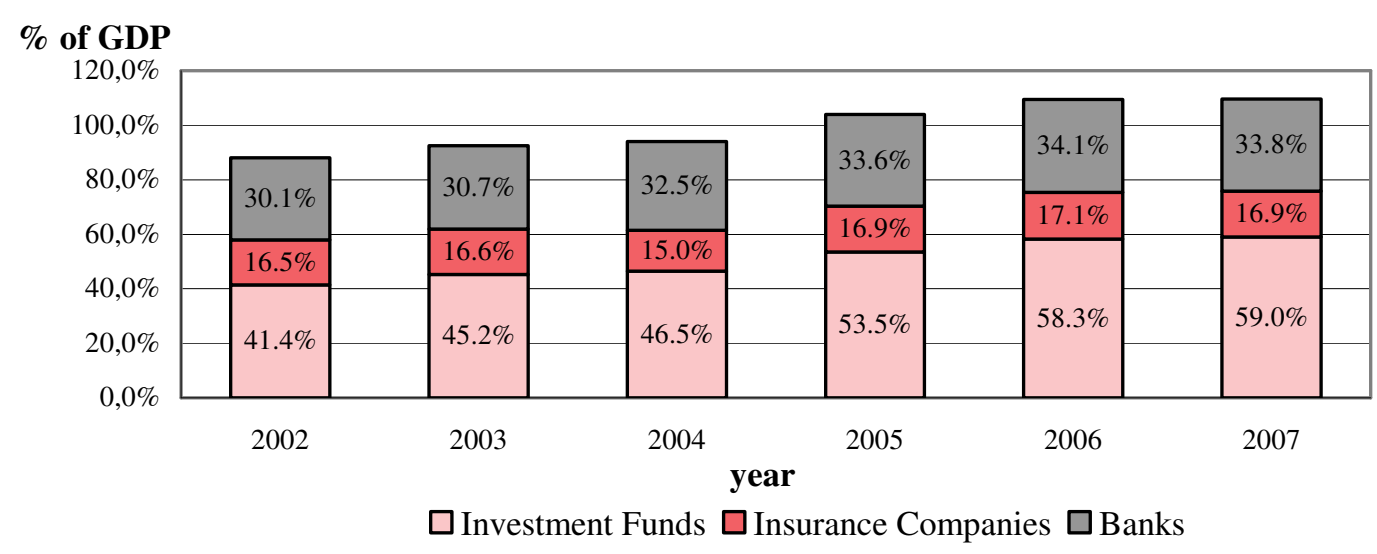

Figure 2: Investments and holdings of German institutional investors ${ }^{12}$

In 2007, equity holdings and share in affiliated companies of German institutional investors amounted $109.7 \%$ of German GDP. The largest share is contributed by investment funds and investment companies, amounting to $59 \%$ of German GDP. German commercial banks are second in terms of their proportion on German GDP with 33.8\%. Last but not least, German insurance companies are third with a share $16.9 \%$ on German GDP. This section showed that institutional investors are on the rise in Germany. It was necessary to present that evidence before analyzing the impact of such a development on activism as well as on corporate governance and corporate management.

\subsection{Demands of Institutional Investors on Corporate Governance}

Initially, it is necessary to point out that it is not possible to illustrate all requirements of institutional investors on corporate governance and corporate management around the world. Therefore, this chapter will exemplarily lay its main focus on the requirements of the California Public Employees Retirement System (further, CalPERS), which is the precursor of institutional activism. Since CalPERS is considered as the worldwide leader and proponent of shareholder activism ${ }^{13}$ by institutional investors, it is central to highlight CalPERS global requirements and standards on corporate governance and corporate management. CalPERS developed its Global Principles of Accountable Governance which basically represents a set of standards that are hold close to those standards adopted by the International Corporate Governance Network (ICGN). ${ }^{14}$ Additionally, CalPERS developed its core principles in order to provide a framework in which CalPERS executes its proxy voting responsibilities. The framework provides a set-up in which it can practice its corporate engagement and governance initiatives. ${ }^{15}$ The main items are therefore outlined below.Generally, CalPERS view on shareholder rights, or in other words, "[...] devices which define the formal relationship between shareholders and the directors to whom they delegate corporate control [...]"16 should be organized as follows:

12 Own calculation and illustration. Source of data: Statistisches Bundesamt (2007), p. 623, Deutsche Bundesbank (2008a), p. 52, Deutsche Bundesbank (2008b), GDV (2007), p. 24.

13 See Smith (1996), p. 228.

14 See CalPERS (2007), p. 6.

15 See CalPERS (2008), p. 5.

16 See CalPERS (2008), p. 17. 
- CalPERS demands that a majority of proxy voting power should be able to change the company's statutes by shareholder proposals. Additionally, a majority of shareholders should be able to call for extraordinary general meetings.

- Regarding the election process of a director, CalPERS recommends that in an uncontested election, a majority of proxy voting power should be required to elect a director. In a contested election, the plurality of proxy voting power should be required. A more important issue is the process of nominating a director. In this context, CalPERS requests that shareowners should have direct access to the nomination process and that additionally directors should be elected annually. Furthermore, CalPERS suggests that shareholders should have cumulative ${ }^{17}$ votes in the election of directors.

- CalPERS also demands that the majority of shareholders should be able to remove a director with or without any reason and that the director has to resign within 90 days after a successful voting.

With respect to the market of corporate control and takeovers, CalPERS demands that companies should allow greenmails. ${ }^{18}$

Additionally, CalPERS demands that no board should be enacted to allow poison pills ${ }^{19}$ without the approval of shareholders. ${ }^{20}$ With regard to minority shareholders, CalPERS requests that the rights of all shareholders should be protected and that all shareholders should be treated equally. ${ }^{21}$ This demand is a logical consequence before the background of "German Inc." and due to the interdependence between different companies and seats on supervisory boards. ${ }^{22}$ Moreover, CalPERS justifies its demands through the potential conflict of interest which could arise between majority shareholders and minority shareholders if the decision making process does not follow the line of argumentation of share price development or valuation. Particularly with regard to the preferential treatment of companies, which are represented on the supervisory board, CalPERS thus suspects a disadvantage to minority shareholders. ${ }^{23}$ Regarding the issue of proxy voting power, CalPERS demands a simplification to boost attendance rates on annual general meetings thus giving the annual general meeting a more legitimate complexion. CalPERS suggests to allow voting via mail or email as well as to abolish the time limit for depositing shares in the forefront of annual general meetings. ${ }^{24}$ Additionally CalPERS demands the abolishment of multiple voting rights which gives a shareholder more votes in contrast to his equity holding. ${ }^{25}$ However, in Germany cumulative

17 Cumulative voting gives shareholders the right to aggregate their votes for one single candidate or distribute these votes to any number of candidates.

18 Greenmailing describes a strategy of corporate raiders to generate large amounts of money via buying a larger share of a targeted company. Instead of completing the hostile takeover attempt, the "green mailer" offers the targeted company to sell its share back to the company at a high premium. In more detail, see Brealy et al. (2006), p. 890 .

19 "Poison pill" describes several methods of takeover defences which could harm the company as well as the potential acquirer. In more detail, see Hockmann and Thießen (2002), p. 172 and p. 195.

20 See CalPERS (2008), pp. 17 et seq.

21 See CalPERS (2007), p. 7.

22 See chapter 4.1.2 above.

23 See Bassen (2002a), p. 39.

24 See Bassen (2002a), p. 39.

25 See CalPERS (2007), p. 7. 
voting was abolished on the $1^{\text {st }}$ of June $2003 .{ }^{26}$ In respect to the constitution and the duties of the supervisory board, CalPERS basically recommends an orientation on the principles of independence and accountability. In particular, CalPERS requests the supervisory board to fulfill the following duties and key functions:

- The board has to review, approve and guide the corporate strategy as well as major plans of action. In addition, the board has to review and approve the corporate risk strategy, annual budgets as well as business plans. As a consequence, the board is obliged to set performance objectives and monitor its implementations as well as corporate performances.

- The board has to select, compensate, monitor and, if necessary, replace key executives.

- The board should align the key executive and board remuneration to the long term interests of the company and its shareholders. Therefore, compensation should consist of a combination of equity-based salary and cash. However, it is important to CalPERS that equity ownership will be encouraged. ${ }^{27}$

- The board should ensure a transparent board nomination and election process.

- The board should be obliged to monitor and manage potential conflicts of interests between corporate management and certain shareholders and stakeholders, e.g. external advisors and service providers. Particularly, the board should ensure that there is no exploitation of corporate assets as well as an abuse in related party transactions.

- The board should ensure the integrity of the corporations accounting and financial reporting systems which includes independent audit, a system for risk management, financial and operational control as well as compliance with the law and relevant standards. Additionally, the board should oversee the process of disclosure and communications. $^{28}$

- Lastly, and most important in respect to the board composition, CalPERS demands that the majority of the board should consist of independent directors. ${ }^{29}$

With regard to the characteristics of an individual director, CalPERS point of view is that each individual director should fit within the skills set identified by the board to fulfill necessary tasks and optimize the company's operating performance. For this reason, the board should have appropriate means to evaluate the performance of each individual director. ${ }^{30}$

\subsection{Importance of Instruments used by Institutional Investors}

After having outlined that shareholder activism has impact on corporate management this section will in particular focus on specific instruments used by institutional investors to influence corporate management. To allow for a more systemized analysis these instruments will be classified into internal and external instruments. External instruments can be characterized by their effects caused through external influences such as market mechanism or laws as well

26 See $\S 5$ AktGEG. The only exception to cumulative voting is if the annual general meeting decides to keep that possibility. However, a two-thirds majority is required according to $§ 5$ (1) 2 AktGEG.

27 See CalPERS (2008), p. 12.

28 See CalPERS (2007), p. 9.

29 See CalPERS (2008), p. 8.

30 See CalPERS (2008), p. 11. 
as through uncooperative behavior of involved parties. In contrast, internal instruments are specified through intra-corporate control mechanism as well as through cooperative behavior of involved parties.

\subsubsection{External Instruments}

\section{Stock sales}

The first external instrument, which has to be pointed out, is the actual sale of stocks (Exit) or the threat to sell stocks. ${ }^{31}$ As a point of origin, shares of companies are tradable at stock markets. A sell-out of shares by institutional investors will have different implications for the management and the corporation. Within international literature, stock sales are considered to be an essential tool to canonize the management of a corporation. However, institutional investors assess stock sales as an instrument with only low to medium relevance.

\section{Perception of Shareholder rights}

In Germany, shareholder rights are basically determined in the German Stock Company Act (further, AktG). Hence, it is incidental that shareholders can monitor and if necessary sue corporations if their rights are violated. However, empirical evidence shows that the instrument to sue a corporation is of minor importance to institutional investors. ${ }^{32}$

\section{Public relations}

With the help of public relations it is possible to rather indirectly influence the management of a corporation. ${ }^{33}$ In particular, institutional investors publish information about their own activities as well as information about certain companies. The target groups of such publications are institutional investors, other shareholders or the management of the targeted company. However, institutional investors use different instruments for public relations such as ranking lists, lists of claims as well as articles in business press. ${ }^{34}$

\section{Annual General Meetings (AGM)}

Annual general meetings can be classified as an external instrument due to the fact that there is no need to directly engage with the management. At these meetings, institutional investors or more commonly speaking, shareholders have three different alternatives to exert their influence. Primarily, shareholders can, according to their shareholdings ${ }^{35}$ directly vote on corporate issues with regard to, e.g. compensation of the management or intended takeovers. ${ }^{36}$ Second, shareholders can bring in new agenda items ${ }^{37}$ even against the interest of the management. Lastly, shareholders have the right to request information about corporate issues ${ }^{38}$ as well as they do have the right of speech at the annual general meeting. ${ }^{39}$ Nonetheless, and especially for small shareholders, it is difficult to exercise their influence on annual general meetings, which is due to their relatively small voting power. ${ }^{40}$

\footnotetext{
See Bassen (2002b), p. 431.

See Bassen (2002a), p. 255.

See Nicolai and Thomas (2004b), p. 455.

See Bassen (2002a), p. 128.

See $\S 130$ AktG.

See Nicolai and Thomas (2004b), p. 455.

See $\S 126$ AktG.

See $\S 131$ AktG.

See $\S 131$ (2) 2 AktG.

See Mackensen (2000), p. 41.
} 


\section{$\underline{3.2 .2 \text { Internal Instruments }}$}

\section{Personal talks}

Shareholders and particularly institutional investors use personal talks to directly mingle with the management (One-on-Ones) as well as with public relations or other departments. On the one hand, personal talks are used to get specific information on corporate issues. On the other hand, personal talks are used to influence corporate management of the organization.

\section{Supervisory board seats}

Basically, every shareholder can be elected from the AGM to the supervisory board in order to monitor and advise the executive board. Institutional investors usually have the edge over minority shareholders due to their larger voting power. Conversely, minority shareholders might have a better linkage or a better relationship to the chairman of the supervisory board or the management board. The instrument to take a seat on the supervisory board is evaluated as of high importance to institutional investors. ${ }^{41}$

\section{Empirical Results on the Success of Activism by Institutional Investors}

The question of success of activism by institutional investors is hardly to answer definitely. Active institutional investors, like CalPERS, are certain that the utility of activism exceeds costs. The range of several analyses varies from "largely successful" 42 to "monitoring [...] is possible" 43 to "no persuasive evidence" 44 . Therefore, the following chapter will review surveys and studies regarding the effectiveness of activism in the United States.

\subsection{Evidence on the Effects of Shareholder Activism in the USA}

First of all, most of the studies do mainly focus on the U.S. capital market, which is due to the fact that the capital market in the United States and, thus, activism is considered to be the precursor in the world. ${ }^{45}$

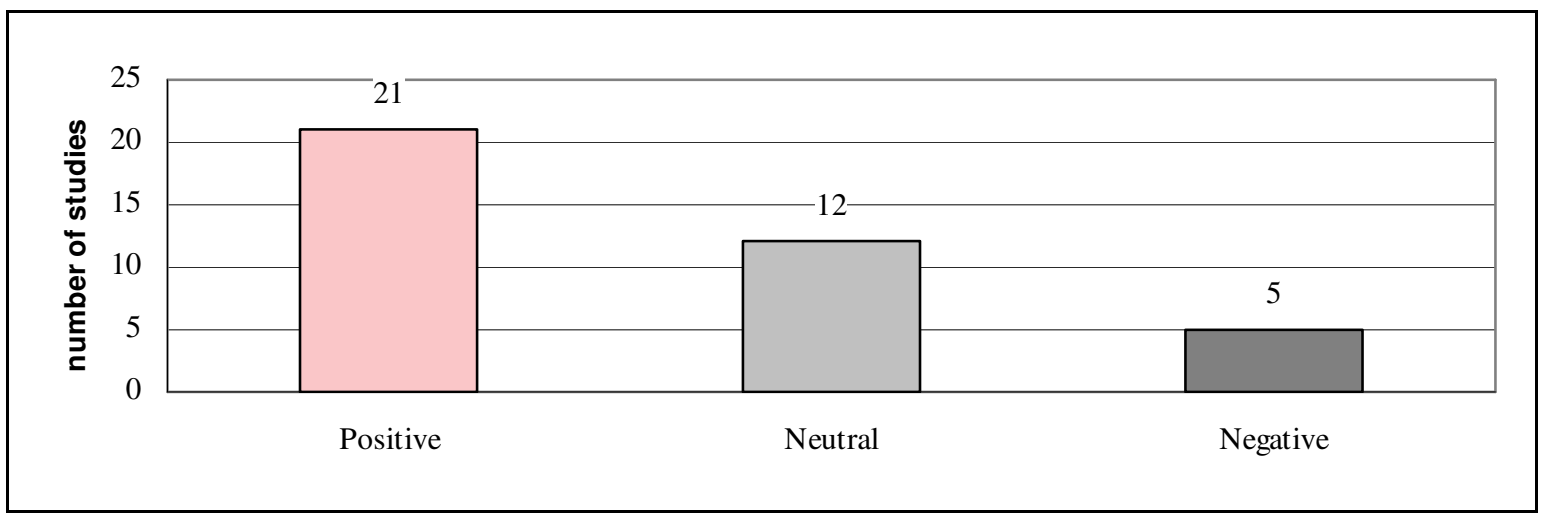

Figure 9: Academic evaluation of shareholder activism in the USA ${ }^{46}$

41 See Bassen (2002a), pp. 140 et seq.

42 See Smith (1996), p. 251. A more recent paper, by Nelson, confirmed these results. See Nelson (2006), p. 205.

43 See Strickland et al. (1996), p. 321.

44 See Hamilton (2000), p. 366.

45 See chapter 4.3 above.

46 Own illustration. 
The evaluation of 38 studies in the U.S. has shown that activism tends to be beneficial in most of the cases.

\subsection{Evidence on the Effects of Shareholder Activism in Germany}

Unfortunately, there are no surveys or studies for the German capital market regarding longterm performance of targeted companies, so far. However, Bassen examined the empirical evidence and the impact of corporate governance for institutional investors as well as for German stock corporations. In general, Bassen found that listed companies evaluate the importance of corporate governance as of high importance. In particular, he compiled that all areas of corporate governance had been adjusted to the demands of institutional investors. Hence, he found clear evidence for the influence of institutional investors, in respect to corporate governance. ${ }^{47}$ Additionally, Bassen analyzed the impact and the exercise of influence by institutional investors on corporate management. Particularly, he evaluated the influence on strategic planning and control, information and communication as well as organization and culture which will be outlined below. ${ }^{48}$

Considering strategic planning and control, Bassen differentiates between long-term company goals, strategic analysis, strategy selection and strategic control. Concerning long-term company goals, Bassens evaluation showed that mission statements and result-oriented goals are of major importance to German corporations as well as to institutional investors. In relation to strategic analysis of the business environment, Bassens study showed that this issue is also of major importance to institutional investors and German companies, although institutional investors examine it significantly higher than companies. Bassen concluded that this appraisal might be a hint for inadequate strategic planning systems. In respect to strategic control, Bassens' study showed that both institutional investors and corporations value strategic control of major importance, although institutional investors evaluate it significantly higher than companies. $^{49}$

Hence, Bassen empirically confirmed his hypopaper that institutional investors comprehensive strategic control is of utmost importance. ${ }^{50}$ Concerning the issue of strategic planning, he differentiates between strategies regarding products/markets, scope of strategies, degree of independence of strategies as well as the mixture of all those. In respect to product and market strategies, Bassen confirmed that institutional investors evaluate strategies, of medium to high importance. Irrespectively of that, he found evidence that the issue of diversification is of more importance to institutional investors with a focus on high-growth companies. In terms of the degree of independence of strategies, the study differentiates between strategic alliances and acquisitions. Concerning acquisition strategies, Bassen found evidence that these strategies are of more importance to German corporations than to institutional investors. Interestingly, the degree of importance to corporations differs in respect to the segment in which corporations are listed.

In summary it becomes apparent that institutional investors do exercise influence on corporate management. Most important to institutional investors are, thus, mission statements of corporations as well as their control. Bassen exemplifies that these areas were already adjusted to the demands of institutional investors. ${ }^{51}$

\footnotetext{
47 See Bassen (2002), p. 260.

48 See Bassen (2002), p. 261.

49 See Bassen (2002), p. 264.

50 See Bassen (2002), p. 227.

51 See Bassen (2002), p. 268.
} 


\section{Conclusion}

The purpose of this document is to answer several research-questions. First, it was necessary to outline the development and the characterization of shareholder activism. Second, the paper should have outlined the demands and requirements of institutional investors on corporate management and corporate governance. In addition to that, the paper aimed at identifying options to exercise influence on corporate. Lastly, the empirical outcomes of activism by institutional investors have been worked out.

From the analysis it can be concluded that institutional shareholder are getting more and more important and that shareholder activism is able to influence corporations as well as corporate governance. Not all questions could be answered. It would be of great interest, whether nonfinancial institutions will also start to publicly exercise influence. Moreover, it would be interesting to know if, due to intensified shareholder activism by institutional investors, a new principal-agent conflict between institutional investors and their financial backer arises. Lastly, it would be interesting to evaluate whether activism has any effect on firm performance in Germany. Up to today, there is no study to be found in academic literature. In conclusion, one can expect that activism by institutional investors in Germany will be enforced.

\section{References}

[1] BASSEN, A. (2002a): Institutionelle Investoren und Corporate Governance - Analyse der Einflussnahme unter Berücksichtigung börsennotierter Wachstumsunternehmen, Wiesbaden: Deutscher Universitätsverlag.

[2] BASSEN, A. (2002b): Einflussnahme institutioneller Anleger auf Corporate Governance und Unternehmensführung - Ergebnisse einer empirischen Untersuchung, in: Zeitschrift für Bankrecht und Bankwirtschaft, vol. 14, issue 5, pp. 430-436.

[3] BEN-UR, D. (2007): Shareholder Activism, Corbin Capital Partners, [online], available: http://www.pionline.com/assets/docs/CO19344522.PDF, [Access: 15.02.2008].

[4] CalPERS (2007): Global Principles of Accountable Corporate Governance, [online], available: http://www.calpers-governance.org/principles/international/global/downloads/global-corpgov-principles.pdf, [Access: 27.01.2008].

[5] CalPERS (2008): Why Corporate Governance today?, website, [online], available: http://www.calpers-governance.org/viewpoint/, [Access: 10.03.2008].

[6] Deutsche Bundesbank (1998), p. 56

[7] Gabler Wirtschaftslexikon (2004): Wirtschaftslexikon, 16th edition, Wiesbaden: Gabler publishing.

[8] GILLAN, STUART L.; STARKS, LAURA T. (2007): The Evolution of Shareholder Activism in the United States, working paper [online], available: http://papers.ssrn.com/sol3/papers. cfm?abstract_id=959670, [Access: 25.03.2008].

[9] HAMILTON, R. W. (2000): Corporate Governance in America 1950-2000, in: Journal of Corporation Law, vol. 25, issue 2, pp. 349-373.

[10] MACKENSEN, M. (2000): Institutionelle Anleger im Unternehmensrecht Deutschlands und der USA, Frankfurt a. Main: Berlin among others: Peter Lang publishing.

[11] NICOLAI, A. T., THOMAS, T. W. (2004b): Kapitalmarktkonforme Unternehmensführung: Eine Analyse im Lichte der jüngeren Strategieprozesslehre, in: Zeitschrift für betriebswirtschaftliche Forschung, vol. 56, issue 8, pp. 452-469.

[12] OECD (2003): Institutional Investors: Statistical Yearbook 1992-2001, Paris: OECD.

[13] OECD (2004): Institutional Investors: Statistical Yearbook, 1992-2001, Paris: OECD.

[14] PORVAZNIK J. AND COLL. (2008): Holistic Management, Pillars of Competence in Management, Bratislava, p. 373, 
[15] SHLEIFER, A., VISHNY, R. W. (1996): A Survey of Corporate Governance, NBER working paper no. W5554, [online], available:

http://papers.ssrn.com/sol3/papers.cfm?abstract_id=10182, [Access: 28.02.2008].

[16] SMITH, M. P. (1996): Shareholder Activism by Institutional Investors: Evidence from CalPERS, in: Journal of Finance, vol. LI, no.1, pp. 227-252.

[17] Statistisches Bundesamt (2007): Statistisches Jahrbuch 2007 - Für die Bundesrepublik Deutschland, [online], available: https://wwwec.destatis.de/csp/shop/sfg/bpm.html.cms.cBroker.cls?cmspath=struktur,vollanzeige.csp $\& \mathrm{ID}=10207001$, [Access: 01.03.2008].

[18] STEIGER, M. (2000): Institutionelle Investoren im Spannungsfeld zwischen Aktienmarktliquidität und Corporate Governance, Baden-Baden: Nomos publishing.

[19] STEINMANN, H., SCHREYÖGG, G. (2005): Management: Grundlagen der Unternehmensführung, 6th edition, Wiesbaden: Gabler publishing.

[20] STRICKLAND, D., KENNETH, W. W., ZENNER, M. (1996): A requiem fort he USA - Is small shareholder monitoring effective? in: Journal of Financial Economics, vol. 40, issue 2, pp. 183-338.

\section{JEL classification: M10, D02}

Michael Diederich M.B.A

Tomas Bata University

Michael.diederich@hvb.de 